Indonesian Science Education Research
(ISER)

\title{
ANALYSIS OF THE EFFECTIVENESS OF APPLYING DISTANCE LEARNING MODELS DURING PANDEMI COVID-19 IN MEDAN CITY
}

\author{
${ }^{1}$ Wahyuni, R., ${ }^{2}$ Fazira, D. A., ${ }^{3}$ Hutasoit, E. S., ${ }^{4}$ Lourenz, T., and ${ }^{5}$ Pardosi, S. \\ ${ }^{1}$ Department of Science Education, Faculty of Mathematics and Natural Science, Universitas Negeri \\ Medan
}

Accepted: May $9^{\text {th }}, 2021$. Published: September $6^{\text {th }}, 2021$

\begin{abstract}
Based on Circular Number 4 of 2020 concerning the Implementation of Education Policies in the emergency period of the spread of the virus, the Minister of Education and Culture urges all educational institutions not to carry out the teaching and learning process directly or faceto-face, but must be done indirectly or remotely. The purpose of this study was to analyze the application of the distance learning model during the Covid-19 pandemic in the city of Medan. The method used in this research is descriptive method with a qualitative approach. The data collection technique uses an online questionnaire. From the results of the survey regarding the use of applications in the learning process, the most are using WhatsApp and Google Class Room. The process of delivering the respondent's subject matter answered sufficiently. The learning method used is the assignment and demonstration method. Assignments are given by the teacher via google form via the whatsapp group or via google class room. Based on the research results, it is concluded that the application of distance learning models (distance learning) cannot be said to be effective as long Covid-pandemic19 in the city of Medan because there were still many obstacles experienced by teachers in the learning process.
\end{abstract}

Keywords: Effectiveness analysis, distance learning model, Covid-19 pandemic 


\section{Introduction}

The Covid-19 pandemic has a major impact on various aspects of Indonesian people's lives. The very fast spread of Covid-19 resulted in the government taking the decision to carry out social distancing and physical distancing to prevent more massive and widespread transmission of the virus. This policy is enforced nationally so that it not only affects the affected areas, but also applies to them there are areas that have not been affected.

In the education sector, the government through the Ministry of Education and Culture called Kemdikbud has implemented a learning from home (BDR) policy, especially for education units located in the yellow, orange and red zones. This refers to the Joint Decree of the Minister of Education and Culture, Minister of Religion, Minister of Health and Minister of Home Affairs regarding Guidelines for Implementation of Learning in the 2020/2021 Academic Year and Academic Year 2020/2021 during the Covid-19 period. For education units that are in the green zone, they can carry out face-to-face learning while still paying attention to health protocols. to prevent the spread of Covid-19, WHO has appealed to stop events that can cause crowds to gather. Therefore, face-toface learning that gathers a large number of students in the class is reviewed for implementation. Lectures must be held in a scenario that is able to prevent physical contact between students and lecturers and students and students (Firman and Rahayu, 2020).

One of the impacts of social distancing also occurs in the learning system in schools. Based on Circular Number 4 of 2020 concerning the Implementation of Education Policies in the emergency period of the spread of the virus, the Minister of Education and Culture urges all educational institutions not to carry out the teaching and learning process directly or face-to-face, but must be done indirectly or remotely. With this appeal, all educational institutions change the learning methods used, namely being online or in a network (online).

In connection with the Covid-19 outbreak in early 2020 , the government then issued an appeal to carry out learning activities from home (Fajrian, 2020). This is done in order to break the chain of spreading the virus and maintain the security and safety of students and educators. With this appeal, the learning process was carried out from home by utilizing internet technology and media. Several studies have shown that technology has many positive effects on language learning, such as reading using videos (Gheytasi, 2015). The internet has been integrated as a tool to complement language learning activities (Martins, 2015). One of the technology media that is often used today is the application on mobile phones. The results showed that students who interact a lot with applications on their cell phones can better understand the contents of the reading text (Gheytasi et al., 2015). Another study tested the reading strategies of students at most Swedish universities. Data is taken from student reading blog activities (Ahmad \& Suyaman, 2018).

According to Dogmen (Rahmawati, 2018) distance learning is learning that emphasizes self-study. Self-learning is organized systematically in presenting learning material, providing guidance to learners, and monitoring for the success of learning. " According to Munir (2012: 16) "distance learning is when the learning process does not occur in the form of faceto-face contact between the teacher and the learner. Communication takes place in two directions which is bridged by media such as computers, television, radio, telephone, internet, video and so on. The purpose of this study was to analyze the effectiveness of applying the distance learning model during the Covid-19 pandemic in the city of Medan.

\section{Research Method}

The method used in this research is descriptive method. Descriptive method is a method used to describe, describe the phenomena that occur. This study uses a qualitative approach to explore, understand, and describe an object of research in a descriptive way in the form of words and language.

The data collection technique in this study used an online questionnaire, namely 
using a google form which was addressed to junior high school science teachers in Medan. The questionnaire contains several written questions that are submitted to respondents to be filled out by them without intervention from researchers or other parties. The data analysis used in this research is qualitative data analysis.

Qualitative data analysis is the effort made by working with data, organizing data, sorting it into manageable units, synthesizing, searching and finding patterns, discover what is important and what is learned This study aims to examine and describe "The Strategy for the Assessment of Student Learning Outcomes by Science Teachers in Medan CityDistance learning (PJJ) ".

This research was conducted online via google form which is distributed in the city of Medan which is aimed at junior high school science teachers.

\section{Result}

\section{Result and Discussion}

The results obtained regarding the analysis of the application of the distance learning model during the Covid-19 pandemic in the city of Medan were 30 respondents.

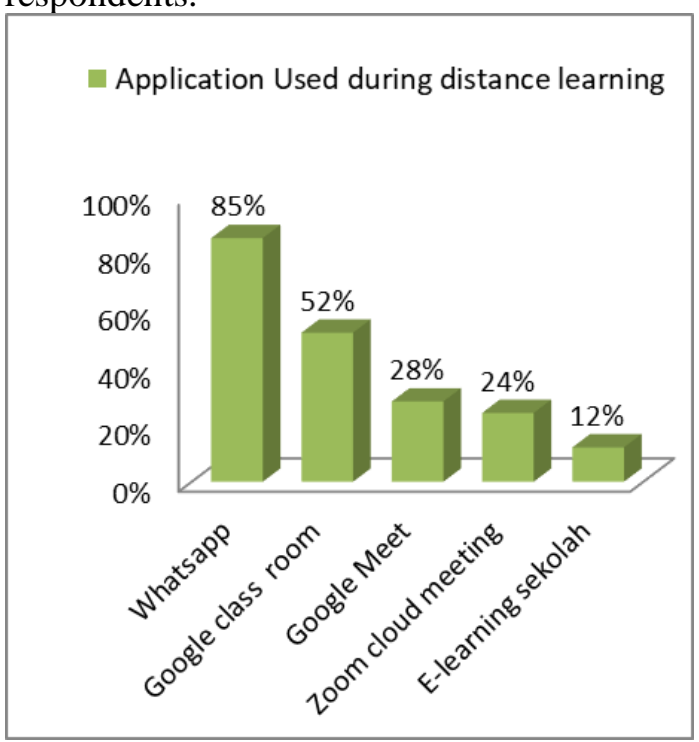

Figure 1. Applications that are used during the process distance learning (distance learning)

Based on Figure 1, the application used during learning is whatsapp as much as
$85 \%$, google class room $52 \%$, zoom meeting $28 \%$, google meet $24 \%$ and school elearning $12 \%$.

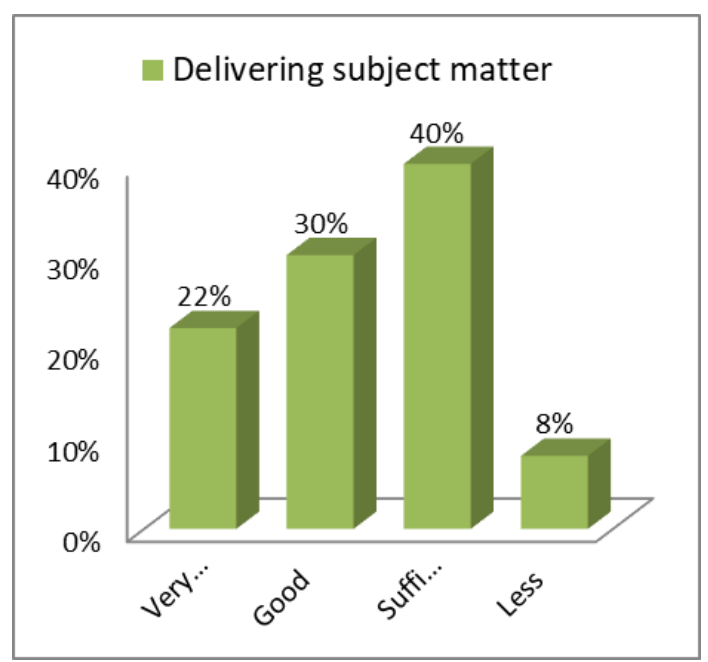

Figure 2. The process of delivering subject matter using a learning model distance (distance learning)

Based on Figure 2 above, information is obtained that learning using the distance learning model in terms of material delivery, obtained that respondents' answers with many answers are sufficient, namely with a percentage of $40 \%$, less $30 \%$, $22 \%$ good and very good $8 \%$.

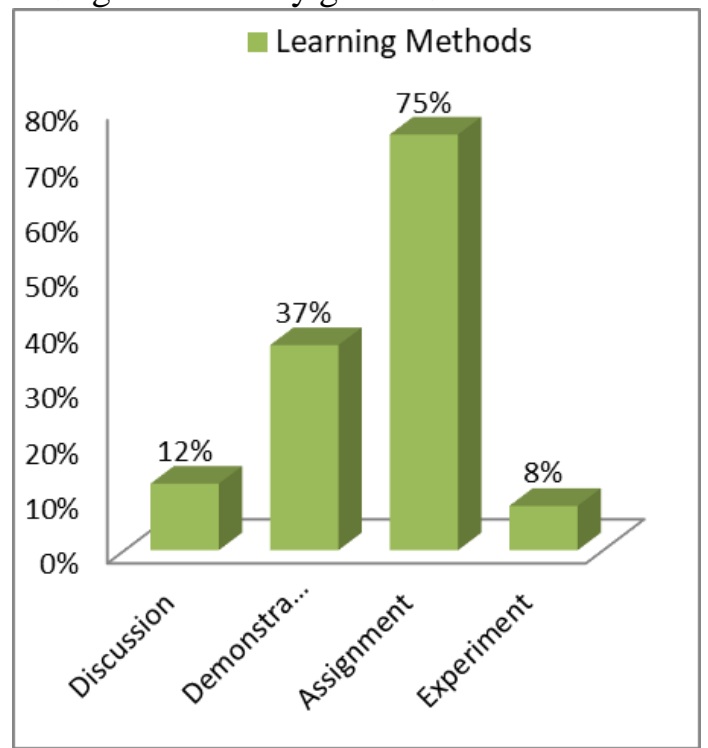

Figure 3. The learning method used during the learning process

Based on Figure 3 above, the learning method used during the distance learning process is mostly using the 
assignment method with a percentage of $75 \%$, demonstration $37 \%$, discussion $12 \%$ and experiment $8 \%$.

\section{Discussion}

Currently the education system is facing many problems, during the COVID19 pandemic, learning in Indonesia has been changed to distance learning, including in the city of Medan. However, the lack of equipment, personnel, resources, and the limitations of educational technology, as well as the skills and quality of the teachers are not sufficient. The use of internet-based media / e-learning has considerable obstacles, especially network connections and technical errors such as server down and error hindering the learning process and success.

The learning process is a communication process, namely the process of delivering messages from message sources through certain channels / media to message recipients. Messages, message sources, channels / media and message recipients are components of the communication process. The learning process can be face-to-face in the classroom and can be via electronic media according to the settings in SAP. The learning process through the internet encourages students to be more active in learning because they have to communicate virtually with teachers and friends.

Distance learning is designed to provide learning with an educational background, varying ages, and places of residence. This distance learning to overcome the limitations of distance, place and time in carrying out the learning process. Therefore, distance learning has different characteristics or characteristics that are different from the conventional faceto-face education system. This characteristic is the physical separation between teacher and learner activities and there is no face-toface presence, resulting in limitations in the learning process.

According to Munir (2012) the characteristics or characteristics of distance learning are as follows: (1) Programs are arranged according to the level, type and nature of education; (2) In the learning process there is no face-to-face meeting between the teacher and the learner, so there is no direct contact between the teacher and the learner; (c) Learners and teachers are separated throughout the learning process because there is no face-to-face like in conventional learning, so learners must be able to learn independently; (4) There is an educational institution that regulates learners to study independently. Distance education is an education system that emphasizes selfstudy; (5) Educational institutions design and prepare learning materials and provide learning assistance services to learners; (6) Learning material is delivered through learning media, such as computers with the internet or by means of e-learning programs; (7) Through such learning media, there will be two-way (interactive) communication between learners and teachers, learners with other learners, or learners with distance learning providers; (8) There is no study group that is permanent throughout the learning period, therefore learners receive learning individually instead of as a group; (9) The new paradigm that occurs in distance learning is the role of the teacher, which is more of a facilitator, who provides assistance or convenience to learners to learn, and learners as participants in the learning process; (10) Learners are required to be active, interactive, and participative in the learning process. because the learning system is independent and has very little help from teachers or other parties; (11) Learning resources are materials that are developed deliberately according to the needs and are based on the curriculum; (12) Learning interactions can be carried out directly if there is a meeting (Sadikin, 2020).

From the results of the survey regarding the use of applications in the learning process, the most were using WhatsApp. Whatsapp is a social media that has features that can save documents in the form of pdf, microsoft word, excel, and powerpoint. It is not surprising that many teachers use WhatsApp as an online learning method application, namely usually using the group whatsapp (WAG) feature. Teachers can create class groups by including students into groups to be able to 
join and carry out discussions and delivery of materials and assignments.

Google classroom is a service from Google that can be used simultaneously to connect educational institutions to switch methods to a paperless system. With google class room, the creation and assignment of tasks can be done through google drive while using gmail to create notifications. In the google classroom classroom, students can be invited to a classroom that has been created by the teacher.

The use of video configuration applications such as zoom meetings and google meet can provide face-to-face online video services between teachers and students in virtual classrooms. Through this video convrences application, teachers can make presentations on subject matter to be conveyed to students.

Implementation of distance learning (distance learning) requires good communication between students, parents, and schools because of the long and impossible distance between students, parents, and the school to be able to meet face to face continuously. communication between students and schools is done in virtual or virtual world. Meanwhile, parents and schools focus more on consultation, discussion, and sharing regarding children's learning development while participating in distance learning and continuing student education after graduating, and the school will also be consulted (Faiqotul, 2015).

The process of delivering subject matter using distance learning models, respondents answered fairly. This is due to some of the obstacles experienced by teachers during the teaching and learning process, such as economic barriers, namely the unavailability of sufficient internet quotas to convey subject matter maximally and effectively, and obstacles to teacher skills in designing learning that are easier for students to understand.

In the implementation of distance learning, obstacles or inconsistencies with learning should be found, many think that the responsibility of teachers in implementing distance learning is much lighter than conventional learning.
The method used by the teacher in implementing distance learning mostly uses the assignment and demonstration method. Assignments are given by the teacher via google form which is shared by the teacher through the WhatsApp group or through the google class room.

The advantages of distance learning models (distance learning)

The distance learning model has several advantages, namely in terms of the efficiency of time and place. Teachers and students can save time to come to school to carry out teaching and learning activities anywhere. The use of costs is also relatively less and the time used is more efficient. The participation of students during online learning is very measurable considering the relaxed learning atmosphere. Students can ask questions freely without feeling afraid and reluctant.

Weaknesses of distance learning models (distance learning).

Besides having advantages, the distance learning model also has several weaknesses, namely, the teacher has difficulty controlling students during the learning process. Teachers also have difficulty seeing students who are really serious and honest in learning and doing school assignments. The level of acceptance of different student subject matter makes the teacher have to be extra extra in delivering the subject matter. Online learning is more dominant theoretical than practical learning because it does not allow direct interaction. In distance learning, teachers rarely provide subject matter with simulations that can be accessed virtually. Teacher found it really difficult to psychologically understand the students (Hardinata, A. 2020).

Thus, distance learning during the Covid-19 Pandemic in Medan cannot be said to be effective. This can be seen from the ability of teachers to use online media in delivering learning materials. Teachers have not been able to manage time, class, and learning methods. The model of distance learning (distance learning) can be said maximally if the teacher can have a clear vision of learning and have a relationship 
with students by performing their role as a motivator, facilitator, mediator and communicator. The application of the distance learning model cannot be said to be effective because teachers have limitations in communicating, interacting, and being creative either due to technical problems such as networks, internet access, or other obstacles. so that students must be able to adapt to the new learning model provided by the teacher. The choice of learning methods that only give assignments without explanation of the material using videos or lectures directly from the teacher can also affect student learning outcomes.

\section{Conclusion}

Based on the results of research on the distance learning process (distance learning) which is sufficient in terms of the delivery of material, and the use of learning methods with assignments, the many obstacles experienced by teachers which cause weaknesses in teaching and learning activities. The application of the distance learning model cannot be said to be effective because teachers have limitations in communicating, interacting, and creating both due to technical disturbances such as networks, internet access, and other obstacles, so that students must be able to adapt to new learning models. given by the teacher. The choice of learning methods that only give assignments without any explanation of the material using videos or lectures directly from the teacher can also affect student learning outcomes.

Thus, it is necessary to improve learning strategies and designs by teachers in using distance learning models (distance learning). Based on the research carried out in terms of increasing online learning, it is necessary to have readiness in terms of internet networks, supporting facilities and infrastructure. In addition, training is needed for teachers in order to increase the capacity of teachers in using and controlling skills in using distance learning applications that can facilitate students in carrying out the learning process.

\section{Reference}

Asumsi. 2020. Problematika Pembelajaran Daring di Masa Pandemi Covid-19 dan Solusi Pemecahannya. Jurnal Pedagogy. 7 (4): 281-288.

Bilfaqih,Y \& Qomarudin,M.N. 2015. Esensi Pengembangan Pembelajaran Daring. Yogyakarta: Deepublish.

Cahyani, A. dkk. 2020. Motivasi Belajar Siswa SMA pada Pembelajaran Daring di Masa Pandemi Covid-19. Jurnal Pendidikan Islam. 3 (1: 123 140.

Darmalaksana,W,dkk. 2020. Analisis Pembelajaran Online Masa WFH Pandemic Covid-19 sebagai Tantangan Pemimpin Digital Abad 21. Karya Tulis Ilmiah (KTI) Masa Work from Home (WFH) Covid-19. $1-12$.

Dewi, W.A.F. 2020. Dampak Covid-19 Terhadap Implementasi Pembelajaran Daring Di Sekolah Dasar. Edukatif: Jurnal Ilmu Pendidikan. 2 (1): 55 - 61.

Hardinata, A., Simatupang, H., Hanifa, F., Latip, A., Efwinda, S., \& Yogica, R. (2020). SURVEY ON THE EFFECTIVENESS OF ONLINE LECTURES DURING COVID-19 PANDEMIC: METHODS AND DIFFICULTIES. Indonesian Science Education Research (ISER), 2(2), 7-12.

Fathoni, A., \& Suyahman. (2018). The Improvement of Social Science Learning 12 Quality Through Applying the Integrated Social Interaction with Modified Behavior (ISOMOKAKU) Learning Model in Elementary School. Jounral of Education Social Science. 9(2) 175179.

Firman,S. \& Rahman, S. R. (2020). Pembelajaran Online di Tengah Pandemi Covid-19. IJES: 
Indonesian Journal of Education Science. 2 (2).

Purnomo, A., Ratnawati, N., \& Aristin, N. F. 2017. Pengembangan Pembelajaran Blended Learning Pada Generasi Z. Jurnal Teori Dan Praksis Pembelajaran IPS. 1 (1): 70-77.

Handarini, O. 2020. Pembelajaran Daring Sebagai Upaya Study from Home (SFH) Selama Pandemi Covid 19. Jurnal Pendidikan Administrasi Perkantoran. 8 (3): 496-503.

Jamaluddin, A. dkk. 2020. Pembelajaran Daring Masa Pandemik Covid-19 Pada Calon Guru: Hambatan, Solusi Dan Proyeksi. Karya Tulis Ilmiah, Lembaga Penelitian dan Pengabdian Kepada Masyarakat UIN Sunan Gunung Djati Bandung.

Jayul, A. Edi, I. 2020. Model Pembelajaran Daring Sebagai Alternatif Proses Kegiatan Belajar Pendidikan Jasmani di Tengah Pandemi Covid19. Jurnal Pendidikan Kesehatan Rekreasi. 6 (2: 190 - 199.

Khusnia,N,dkk. 2019. Efektifitas Pembelajaran Berbasis Daring. Jurnal Tatsqif. 17 (1): 19-33.

Lestari, Selvy Windy. 2020. Kendala Pelaksanaan Pembelajaran Jarak Jauh (PJJ) Dalam Masa Pandemi Ditinjau Dari Media Pembelajaran. Jurnal Ilmu Pendidikan. 2 (3): 1324.

Nakayama M, Yamamoto H, \& S. R. 2007. The Impact of Learner Characterics on Learning Performance in Hybrid Courses among Japanese Students. Elektronic Journal E-Learning, 5 (3).

Nikmah, F.I. 2016. Manajemen Pembelajaran Jarak Jauh (Distance Learning) Pada Homeschooling "Sekolah Dolan"'. Jurnal Manajemen Pendidikan. 25 (1) 112 19.
Rohmawati, A. 2015. Efektivitas Pembelajaran. Jurnal Pendidikan Usia Dini. 9 (1): 15-32.

Sadikin,A,dkk. 2020. Pembelajaran Daring di Tengah Wabah Covid-19. Jurnal Ilmiah Pendidikan Biologi. 6 (2): 214-224. 